\title{
A New Possible Atomic Arrangement for the Carbon Atom in the B-Sites of Ab-Type Carbonate Apatite
}

Jorge Correa de Araujo , Elizabeth Lima Moreira ${ }^{\mathrm{b}}$, Valeria Conde Alves Moraes ${ }^{\mathrm{b}}$,

Ana Paula Duarte Moreirac*, Glória Dulce de Almeida Soares ${ }^{\mathrm{c}}$

${ }^{a}$ Rio de Janeiro State University - UERJ, CEP 24435-000, São Gonçalo, RJ, Brazil

${ }^{\mathrm{b}}$ Brazilian Center for Physics Research-CBPF, CEP 22290-180, Rio de Janeiro, RJ, Brazil

${ }^{\mathrm{C} C O P P E}$ and Polytechnic School, Federal University of Rio de Janeiro - UFRJ,

CEP 21941-972, Rio de Janeiro, RJ, Brazil

Received: March 17, 2011; Revised: July 21, 2011

\begin{abstract}
The crystal structure of a synthetic AB-type carbonate apatite sample was analyzed by Rietveld refinement including a model with carbon atom not fixed in the B-site of the apatite structure. Only one constraint was applied to this model: the fractional occupancies of the atoms in the $\mathrm{CO}_{3}$ ion plus $\mathrm{PO}_{4}$ ion were equal 1.0 per phosphate site with six sites per unit cell. Rietveld refinement of the crystal structure with space group $\mathrm{P}_{3} / \mathrm{m}$ results in cell parameters $\mathrm{a}=9.3583(1) \AA$ and $\mathrm{c}=6.9226(5) \AA ; \mathrm{Z}=1 ; \mathrm{R}_{\mathrm{wp}}=0.0824$ and 9.5 wt. $(\%)$ of carbonate in this structure. The use of simple geometry formulas showed that the $\mathrm{C}$ atom is not located at the center of the equilateral triangle of oxygen $\mathrm{O} 2, \mathrm{O} 3$ and $\mathrm{O}^{\prime}$ ', but to a distance $0.18 \AA$ of this triangle. The results seem to indicate a new 3-D crystal structure of the carbonated apatite in $\mathrm{PO}_{4}$ groups.
\end{abstract}

Keywords: rietveld, refinement, carbonate, crystal structure

\section{Introduction}

Calcium phosphates are currently employed as bone substitute in several clinical applications due their similarity with bone ${ }^{1}$. The crystal structure of hydroxyapatite, $\left(\mathrm{HA}-\mathrm{Ca}_{10}\left(\mathrm{PO}_{4}\right)_{6}(\mathrm{OH})_{2}\right)$, allows several ionic substitutions. The incorporation of carbonate ions into the HA structure improves its biological properties as it becomes closely to the composition of the mineral part of bone tissue. For instance, a carbonate ion can replace two different sites in HA lattice: the $\mathrm{OH}$ ion (A-site or channel site) and the $\mathrm{PO}_{4}$ site (B-site), increasing apatite solubility.

A deep study in the calcium phosphate structure is important to understand in vivo response. However, the crystal structure of carbonate apatite remains unclear due to uncertainties in the exact localization of the $\mathrm{CO}_{3}$ ions ${ }^{2}$. As noticed by Fleet and Liu (2003) ${ }^{3}$ changes in $a(=b)$ and $c$ unit cell parameters of carbonate apatite $\left(\mathrm{CO}_{3}\right.$-apatite) were observed, comparing with cell parameters of a pure hydroxyapatite. Suetsugu et al. ${ }^{4}$ analyzed the structure of A-type carbonate apatite with partial occupancy in B sites and observed that $a$ parameter took a middle point of the pure HA and the A-type $\mathrm{CO}_{3}$-apatite powder reference, while $c$ parameter was larger in comparison with the pure HA. In our previous work ${ }^{5}$, the $\mathrm{X}$-ray diffraction profile of the $\mathrm{AB}$-type $\mathrm{CO}_{3}$-apatite synthetic powder showed a contraction of the $a$ lattice parameter and an enlargement of $c$ lattice parameter. The decreasing of the occupancy factor (O.F.) of $\mathrm{P}$ sites is another partial evidence of the replacement of $\mathrm{CO}_{3}$ ions in the structure of the apatite ${ }^{2}$.

Elliot ${ }^{6}$ showed that the planes containing $\mathrm{CO}_{3}$ triangles are nearly parallel to the $c$ axis, when the carbonate ions replace $\mathrm{OH}$ groups (A-site) in the channels. When the carbonate ions replace the $\mathrm{PO}_{4}$ groups, the planes with $\mathrm{CO}_{3}$ triangles make a $37 \pm 4^{\circ}$ angle with $c$-axis, and the triangle occupies the sloping face of the tetrahedron. However, according to Wilson et al. ${ }^{7}$, different locations of the $\mathrm{CO}_{3}$ ion in the $\mathrm{AB}$ - type $\mathrm{CO}_{3}$-apatite can be obtained, probably due to differences in apatite synthesis.

Ivanova et al. $^{2}$ has analyzed carbonated hydroxyapatite powder samples by X-ray diffraction and has observed that the carbonate ions randomly occupy two adjacent faces of the $\mathrm{PO}_{4}$ tetrahedron, parallel to the $c$-axis, indicating that three oxygen atoms $\mathrm{O} 1, \mathrm{O} 2$ and $\mathrm{O} 3$ (split in two $\mathrm{O} 3$ ) of the $\mathrm{PO}_{4}$ tetrahedron make up the coordination for the two carbon atoms labelled $\mathrm{C} 1$ and $\mathrm{C} 2$. The discrepancies amidst the data of different authors seem to indicate that carbonate triangles may occupy any of the tetrahedral faces, but in each specific case, they can be found to stick to a certain face ${ }^{2}$.

In this paper, XRD data of an $\mathrm{AB}$-type $\mathrm{CO}_{3}$-apatite sample was analyzed by Rietveld refinement ${ }^{8}$, using a different approach in which, the $\mathrm{CO}_{3}$ ion is allowed to move freely during the refinement, in order to determine the $\mathrm{C}$ position and the oxygen coordination in $\mathrm{PO}_{4}$ group.

\section{Materials and Method}

\subsection{AB-type carbonated apatite sample ( $\mathrm{CO}_{3}$-apatite)}

$\mathrm{CO}_{3}$-apatite was synthesized by wet precipitation method using calcium nitrate $\left(\mathrm{Ca}\left(\mathrm{NO}_{3}\right)_{2} \cdot 4 \mathrm{H}_{2} \mathrm{O}\right)$, diammonium hydrogen phosphate $\left(\left(\mathrm{NH}_{4}\right)_{2} \mathrm{HPO}_{4}\right)$ and ammonium carbonate $\left(\left(\mathrm{NH}_{4}\right)_{2} \mathrm{CO}_{3}\right)$ solutions as precursors. The temperature and $\mathrm{pH}$ were maintained at $3{ }^{\circ} \mathrm{C}$ and 12 , respectively ${ }^{5}$. This sample was heat treated at $500{ }^{\circ} \mathrm{C}$ for 6 hours and examined by X-ray diffraction using a XRD Rotaflex (Rigaku, Japan) with $\mathrm{CuK}_{\alpha}$ radiation and graphite monochromator, spectra $2 \theta 10^{\circ}-100^{\circ}$ with the step of $0.02 / 5 \mathrm{~s}$ per data point. The $\mathrm{CO}_{3}$ content on green and calcined powder was determined by temperature-programmed desorption coupled to mass spectrometer (TPD-MS) being equal to 16.2 and 12.8 wt. (\%), respectively. As the green sample was submitted to thermal treatment at $500{ }^{\circ} \mathrm{C}$, 
any carbonate bonding superficially was eliminated, decreasing the carbonate content of the calcined sample. The complete description of synthesis and characterization results can be found elsewhere ${ }^{9}$.

\subsection{Rietveld refinement}

Rietveld refinements were carried out employing the FULLPROF program $^{10}$ and a Pearson VII function was used particularly to fit anisotropic broadening of Bragg $\mathrm{OOl}$ reflections caused by the strain in the reticulate, the crystallite size and the instrument. Initially, for the refinement of the apatite structure without explicit inclusion of $\mathrm{CO}_{3}$ ion, the structure of Holly Springs hydroxyapatite single crystal structure ${ }^{11}$ was used. This model, called A model, space group $\mathrm{P}_{3} / \mathrm{m}$, was used as the starting model for refinement.

Another model, B model, also space group $\mathrm{P}_{3} / \mathrm{m}$, was created adding $\mathrm{C}$ atom in the structure of the refined $\mathrm{A}$ model, with the $\mathrm{CO}_{3}$ ion occupying $\mathrm{PO}_{4}$ sites. The model for the $\mathrm{CO}_{3}$ ion (model B), similar to the calcite structure, was proposed considering that the $\mathrm{z}$ position of the $\mathrm{C}$ atom can be varied. This strategy was firstly adopted by Wilson et al. ${ }^{12}$ that proposed an initial triangular geometry for the $\mathrm{CO}_{3}$ ion, with C-O and O-O distances of 1.294 and $2.413 \AA$, respectively. In their studies, these distances were maintained by the soft constraints, while the $\mathrm{O} 1$ position of the $\mathrm{CO}_{3}$ ion was hard constrained to have the same position of $\mathrm{O} 1$ in the $\mathrm{PO}_{4}$ ion. Contrary, in our study, the initial geometry for the $\mathrm{CO}_{3}$ ion in model $\mathrm{B}$ was allowed to move freely during the refinement. Only one constraint was applied: the fractional occupancies of the atoms in the $\mathrm{CO}_{3}$ ion plus $\mathrm{PO}_{4}$ ion were equal 1.0 per phosphate site with six sites per unit cell.

The isotropic displacement parameters were refined in all refinements performed. The preferred orientation (March-Dollase) parameter was allowed to vary, but it was fixed at 1.0 because the refinement indicated no preferred orientation. The background was modeled with the linear polynomial ${ }^{13}$.

\section{Results and Discussion}

The refinement of the observed and calculated XRD patterns of $\mathrm{CO}_{3}$-apatite is shown in Figure 1 and was in good agreement as the average $R_{w p}, R_{B}$ and $R_{F}$ values were, respectively, 0.0824, 0.0256 and 0.0195 .

Table 1 shows some crystal data obtained for $\mathrm{CO}_{3}$-apatite sample using Model A and Model B. Data from the literature for $\mathrm{HA}^{11}$ and B-type $\mathrm{CO}_{3}$-ap ${ }^{2}$ are also included.

As told before, the A model was used only as the starting model for refinement of the $\mathrm{B}$ model with the inclusion of the $\mathrm{C}$ atom in the structure. Both models showed an important and similar reduction in P occupancy ( $20 \%$ for model A and $\sim 18 \%$ for model B). However, the two models are not directly comparable. For example, the model $\mathrm{B}$ has a constraint about the complementary crystallography condition of the occupation factors of $\mathrm{P}$ and $\mathrm{C}$ (B-site) while the A model has no constraint about these occupancies factors.

Comparing cell parameters of B model with data for HA (Table 1), a reduction in the a parameter, and a large increasing in the $\mathrm{c}$ parameter is observed. The a parameter is smaller than that reported by Ivanova ${ }^{2}$ (9.437 $\AA$ ), but agrees with Wilson et al. ${ }^{12}$ data $(\mathrm{a}=9.3446(3) \AA$ and $\mathrm{c}=(6.9199(4) \AA)$ for a carbonate apatite with $\mathrm{CO}_{3}$ content equal to 12.6 wt. (\%) and some residual sodium. In this case, the reduction of a parameter occurs because the carbonate ion is smaller than phosphate ion. According to Wilson et al. ${ }^{12}$, the a-axis contraction for a $\mathrm{CO}_{3}$-apatite depends on the method and conditions of precipitation. The replacement by carbonate ion generates a large structural disorder creating vacancies of $\mathrm{Ca}$ and $\mathrm{OH}$ ions. This disorder is also reflected in periodicity of the crystallographic planes observed by X-ray ${ }^{14}$, resulting in a decrease of the a parameter.

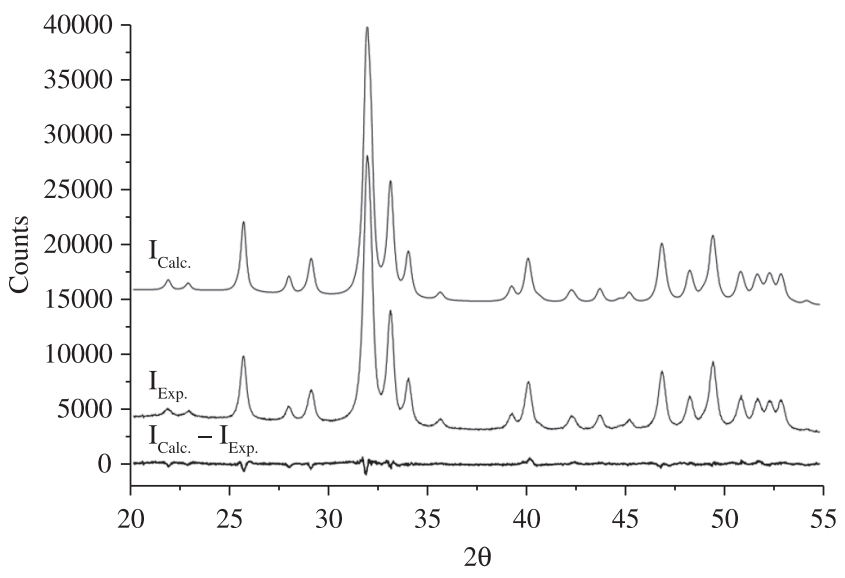

Figure 1. Final fit between experimental and $\mathrm{B}$ model calculated XRD pattern of the $\mathrm{CO}_{3}$-apatite calcined at $500{ }^{\circ} \mathrm{C}$ during 6 hours.

The results for $\mathrm{C} 2$ atom position using model $\mathrm{B}$ is in reasonable agreement with those obtained by Ivanova et al. ${ }^{2}$ for B-type $\mathrm{CO}_{3}$-apatite and with the $(0.408(1), 0.398(1), 0.187(2))$ position for atom $\mathrm{C}$ obtained by Wilson et al. ${ }^{12}$.

In the B model, the reduced occupancy values, 0.82 and 0.39 for $\mathrm{P}$ and $\mathrm{O} 4 \mathrm{~h}$ atoms, respectively, are partial evidence of the incorporation of $\mathrm{CO}_{3}$ ions in sites $\mathrm{A}$ and $\mathrm{B}$. No vacancy was observed in $\mathrm{O} 1$ sites, which exhibit an occupancy factor (O.F.) equal to 1.02(4). Therefore, we suggested that the $\mathrm{CO}_{3}$ ions occupy the sites $\mathrm{O} 2$ and $\mathrm{O}^{\prime}$ ' of a replaced $\mathrm{PO}_{4}$ ion, with O.F. equal to 0.054(8) and 0.08(1), respectively.

From occupancies factors obtained by refinement for $\mathrm{Ca}, \mathrm{P}$, $\mathrm{C} 2$ and $\mathrm{O} 4$ atoms (Table 1), the chemical formula for $\mathrm{CO}_{3}$-apatite employed in this study is $\mathrm{Ca}_{9.408}\left[\left(\mathrm{PO}_{4}\right)_{4.92}\left(\mathrm{CO}_{3}\right)_{1.08}\right]\left[(\mathrm{OH})_{1.56}\left(\mathrm{CO}_{3}\right)_{0.44}\right.$, resulting in approximately $9.5 \mathrm{wt}$. (\%) of carbonate in this structure and $\mathrm{Ca} / \mathrm{P}$ ratio equal to 1.912 . The theoretical value (obtained by refinement) for carbonate content is quite different from the experimental data $(12.8 \mathrm{wt}$. (\%)).

The maximum and minimum residual electron densities for the eight atomic cell positions in the B model were, respectively, $\Delta \rho=0.16\left(\mathrm{e}^{-3}\right)$ and $\Delta \rho=-0.15\left(\mathrm{e}^{-3}\right)$. This data shows that $\mathrm{F}_{\mathrm{o}} \approx \mathrm{F}_{\mathrm{c}}$, where $\mathrm{F}_{\mathrm{o}}$ is the observed structure factor and $\mathrm{F}_{\mathrm{c}}$ is the structure factor calculated by the model. Unfortunately, the $\mathrm{C}$ position in coordination with the O2-O3-O3' oxygen was not clearly determined by X-Fourier maps (not shown). Consequently, the lower residual scattering around the $\mathrm{P}$ atom was not undoubted identified as a $\mathrm{CO}_{3}$ ion.

The application of simply analytical geometry formulas and geometrical transformations of three dimensions confirm that the $\mathrm{C}$ atom is not fixed in the center of the O2-O3-O3' triangles, but at $0.18 \AA$ of this tetrahedral face. The transformation matrix $[\mathrm{a}, 0,0 /-0.5 \mathrm{a}, 0.5 \sqrt{3} \mathrm{a}, 0 / 0,0, \mathrm{c}]$ turns the hexagonal crystal system into an orthogonal system.

The plane face of $\mathrm{CO}_{3}$ ion formed by only O2-O3-O3' triangle is parallel to $c$ axis in agreement with the results obtained by Ivanova et al. ${ }^{2}$. It seems that the environment around the $\mathrm{C}$ atom is not strictly distorted, although the distance for $\mathrm{C}-\mathrm{O}$ bond $(1.36 \AA)$ suggests that the $\mathrm{C}$ atom is weakly bounded with the oxygen coordination. Therefore, the geometry for $\mathrm{CO}_{3}$ ion in $\mathrm{PO}_{4}$ vacancies sites is a small tetrahedron of $0.164 \AA^{3}$ in comparison with $1.70 \AA^{3}$ for the $\mathrm{PO}_{4}$ tetrahedral volume.

This little tetrahedral configuration for the $\mathrm{CO}_{3}$ ion seems to contradict the previous Rietveld studies realized by Ivanova et al. ${ }^{2}$ and Wilson et al. ${ }^{12}$, but in their investigations, the constraints were 
Table 1. Cell, positional and occupancy parameters of the crystal structure.

\begin{tabular}{|c|c|c|c|c|c|}
\hline \multirow{3}{*}{$\begin{array}{l}\text { Method of } \\
\text { Refinement }\end{array}$} & \multicolumn{2}{|c|}{$\mathrm{CO}_{3}$-apatite sample } & & \multirow{2}{*}{\multicolumn{2}{|c|}{ B-type $\mathrm{CO}_{3}$-apatite ${ }^{2}$}} \\
\hline & Model A & Model B & $\mathrm{HA}^{11}$ & & \\
\hline & Rietveld & Rietveld & $\begin{array}{c}\text { Refinement with } \\
\text { neutrons }\end{array}$ & \multicolumn{2}{|c|}{ Rietveld } \\
\hline \multicolumn{6}{|c|}{ Cell parameters $(\AA)$} \\
\hline$a(=b)$ & $9.3576(4)$ & $9.3583(4)$ & $9.424(4)$ & \multicolumn{2}{|c|}{$9.437(1)$} \\
\hline$c$ & $6.9222(3)$ & $6.9226(4)$ & $6.879(4)$ & \multicolumn{2}{|c|}{$6.881(1)$} \\
\hline \multicolumn{6}{|c|}{ Positional and occupancy factors parameters and Wyckoff index } \\
\hline \multicolumn{6}{|l|}{$\mathrm{Ca} 14 \mathrm{f}$} \\
\hline $\mathrm{z}$ & $0.0020(0)$ & $0.0020(0)$ & $0.0015(1)$ & \multicolumn{2}{|c|}{$0.0011(3)$} \\
\hline Occupancy & $0.981(5)$ & $0.957(2)$ & 1.0 & \multicolumn{2}{|c|}{$0.848(2)$} \\
\hline \multicolumn{6}{|l|}{$\mathrm{Ca} 26 \mathrm{~h}$} \\
\hline $\mathrm{x}$ & $0.2430(2)$ & $0.2437(2)$ & $0.2468(2)$ & \multicolumn{2}{|c|}{$0.2457(2)$} \\
\hline $\mathrm{y}$ & $0.9884(3)$ & $0.9877(3)$ & $0.9934(1)$ & \multicolumn{2}{|c|}{$0.9879(2)$} \\
\hline Occupancy & $0.910(1)$ & $0.93(1)$ & 1.0 & \multicolumn{2}{|c|}{$0.985(2)$} \\
\hline \multicolumn{6}{|l|}{ P $6 \mathrm{~h}$} \\
\hline $\mathrm{x}$ & $0.3964(6)$ & $0.4018(6)$ & $0.3987(2)$ & \multicolumn{2}{|c|}{$0.3991(3)$} \\
\hline y & $0.3705(4)$ & $0.3770(4)$ & $0.3658(1)$ & \multicolumn{2}{|c|}{$0.3692(3)$} \\
\hline Occupancy & $0.796(5)$ & $0.820(9)$ & 1.0 & \multicolumn{2}{|c|}{$0.824(3)$} \\
\hline \multicolumn{6}{|l|}{ O16h } \\
\hline $\mathrm{x}$ & $0.3290(6)$ & $0.3290(6)$ & $0.3284(2)$ & \multicolumn{2}{|c|}{$0.3264(5)$} \\
\hline $\mathrm{y}$ & $0.4863(9)$ & $0.4863(9)$ & $0.4848(2)$ & \multicolumn{2}{|c|}{$0.4829(5)$} \\
\hline Occupancy & $1.188(9)$ & $1.02(4)$ & 1.0 & \multicolumn{2}{|c|}{$0.932(5)$} \\
\hline \multicolumn{6}{|l|}{$\mathrm{O} 26 \mathrm{~h}$} \\
\hline $\mathrm{x}$ & $0.5851(5)$ & $0.5893(5)$ & $0.5873(2)$ & \multicolumn{2}{|c|}{$0.5879(6)$} \\
\hline y & $0.4620(8)$ & $0.4625(8)$ & $0.4651(2)$ & \multicolumn{2}{|c|}{$0.4695(6)$} \\
\hline Occupancy & $1.144(8)$ & $0.946(8)$ & 1.0 & \multicolumn{2}{|c|}{$0.945(5)$} \\
\hline O3 12i* & & & & O3p & $\mathrm{O} 3 \mathrm{c}$ \\
\hline $\mathrm{x}$ & $0.3448(5)$ & $0.3481(5)$ & $0.3437(2)$ & $0.3409(4)$ & $0.362(4)$ \\
\hline $\mathrm{y}$ & $0.2612(4)$ & $0.2613(4)$ & $0.2579(1)$ & $0.2579(4)$ & $0.299(4)$ \\
\hline $\mathrm{z}$ & $0.0693(4)$ & $0.0693(4)$ & $0.0702(2)$ & $0.0668(4)$ & $0.089(4)$ \\
\hline Occupancy & $0.883(9)$ & $0.928(1)$ & 1.0 & $0.832(9)$ & $0.187(9)$ \\
\hline $\mathrm{O} 44 \mathrm{e}$ & & & & & \\
\hline $\mathrm{z}$ & $0.182(2)$ & $0.170(1)$ & $0.1978(7)$ & & \\
\hline Occupancy & $0.360(3)$ & $0.390(4)$ & 0.5 & & \\
\hline $\mathrm{C} 26 \mathrm{~h}$ & N.I. & & N.I. & & \\
\hline $\mathrm{x}$ & & $0.4435(5)$ & & $0.4380^{* * *}$ & \\
\hline y & & $0.3190(6)$ & & $0.3550^{* *}$ & \\
\hline $\mathrm{z}$ & & $0.2256(2)$ & & $0.2500^{* *}$ & \\
\hline Occupancy & & $0.18(2)$ & & $0.09(1)$ & \\
\hline
\end{tabular}

N.I. = not included in the refinement. *The O3 atom was splitted into two O3p and O3c by D-Fourier maps. **Not refined by Ivanova et al. (2001). 
applied in the $\mathrm{CO}_{3}$ ion geometry to maintain the $\mathrm{C}$ carbon atom in the center of the equilateral triangle of oxygen atoms.

\section{Conclusions}

The Rietveld refinement of XRD data of the carbonated apatite crystal structure with explicit inclusion of $\mathrm{CO}_{3}$ ions considering $\mathrm{B}$ model showed that the $\mathrm{C}$ atom is weakly bounded with the only $\mathrm{O} 2$, $\mathrm{O} 3$ and $\mathrm{O}^{3}$ 'oxygen of the replaced $\mathrm{PO}_{4}$ ions and $0.18 \AA$ distant of this plane face. The refinement in occupancies for the $\mathrm{CO}_{3}$ and $\mathrm{PO}_{4}$ ions resulted in $\sim 9.5 \mathrm{wt}$. (\%) of carbonate in this structure. The results seem to indicate a new possible crystal structure of carbonate group in phosphate site with $\mathrm{CO}_{3}$ ion occupying a small tetrahedral volume $\left(0.164 \AA^{3}\right)$ when compared with the $\mathrm{PO}_{4}$ tetrahedral $\left(1.70 \AA^{3}\right)$.

\section{Acknowledgements}

The authors would like to thank Faperj, CNPq and CAPES for financial support.

\section{References}

1. Costa NMF, Melo BR, Brito RT, Fernandes GVO, Bernardo VG, Fonseca EC et al. Quality and Intensity of the Tissue Response to Two Synthetic Granular Hydroxyapatite Implanted in Critical Defects of Rat Calvaria. Materials Research, 2009; 12(2):245-51. http://dx.doi.org/10.1590/ S1516-14392009000200022

2. Ivanova TI, Frank-Kamenetskaya OV, Kol'tsov AB and Ugolkov VL. Crystal Structure of Calcium-Deficient Carbonated Hydroxyapatite. Thermal Decomposition. Journal of Solid State Chemistry. 2001; 160(2):340-49. http://dx.doi.org/10.1006/jssc.2000.9238

3. Fleet, ME and Liu X. Location of type B carbonate ion in type A-B carbonte apatite synthesized at high pressure. Journal of Solid State Chemistry. 2004; 177:3174-82. http://dx.doi.org/10.1016/j. jssc.2004.04.002
4. Suetsugu Y, Takahashi Y, Okamura FP and Tanaka J. Structure Analysis of A-Type Carbonate Apatite by a Single-Crystal X-Ray Diffraction Method. Journal of Solid State Chemistry. 2000; 155:292-97. http://dx.doi.org/10.1006/jssc.2000.8887

5. Moreira EL, Araujo JC, Moraes VCA and Moreira APD. Análise por Difração de Raio-X de uma Hidroxiapatita Carbonatada Usando o Método de Rietveld. Revista Matéria. 2007; 11(3):494-502.

6. Elliott JC. Structure and Chemistry of Apatites and Other Calcium Orthophosphates. Amsterdam: Elsevier Science B.V.; 1994. Studies in Inorganic Chemistry 18.

7. Wilson RM, Stephanie EP and Elliot JC. Rietveld refinement and spectroscopic structural studies of a Na-free carbonate apatite made by hydrolysis of monetite. Biomaterials. 2006; 27:4682-92. http://dx.doi. org/10.1016/j.biomaterials.2006.04.033

8. Rietveld HM. Line Profiles of Neutron Powder-Diffraction Peaks for Structure Refinement. Acta Crystallographica. 1967; 22(1):151-52. http://dx.doi.org/10.1107/S0365110X67000234

9. Moreira APD. Síntese e Caracterização de Carbonato Apatitas Nanoestruturadas. [Dissertação]. Rio de Janeiro: Universidade Federal do Rio de Janeiro, Instituto de Química; 2006.

10. Rodriguez-Carvajal J. FullProf 2000. Available from: <http://www-llb. cea.fr/fullweb>. Access in: 05/2010.

11. Sudarsanan K and Young RA. Significant Precision in Crystal Structural Details: Holly Springs Hydroxyapatite. Acta Crystallographica. 1969; B25:1534-43.

12. Wilson RM, Elliot JC, Stephanie EPD and Smith RI. Rietveld structure refinement of precipitated carbonate apatite using neutron diffraction data. Biomaterials. 2003; 25:2205-13. http://dx.doi.org/10.1016/j. biomaterials.2003.08.057

13. Bigi A, Ripamonti A, Brückner S, Gazzano M, Roveri N and Thomas AS. Structure Refinements of Lead-Substituted Calcium Hydroxyapatite by X-Ray Powder Fitting. Acta Crystallographica. 1989; B45:247-51.

14. Astala $\mathrm{R}$ and Stott MJ. First Principles Investigation of Mineral Component of Bone: $\mathrm{CO}_{3}$ Substitution in Hydroxyapatite. Chemistry of Materials. 2005; 17:4125-33. http://dx.doi.org/10.1021/cm050523b 